\title{
Study on the Cultivation of Teachers' Professional Quality in Higher Vocational Colleges in the New Era
}

\author{
Xia Lei \\ Chongqing Business Vocational College \\ Chongqing, China
}

\begin{abstract}
The development of socialism with Chinese characteristics has entered a new era, the development of technologies such as the Internet and artificial intelligence has also had a major impact on the development of higher vocational education, higher vocational education has also entered a new era with new development opportunities and new challenges, therefore, based on the definition of quality and attainment, this paper analyzes the seven professional qualities of teachers in higher vocational colleges in the new era, and puts forward a cultivation path combining self-cultivation and institutional training, to provide enlightenment and reference for the cultivation of teachers' professional quality in higher vocational colleges in the new era.
\end{abstract}

Keywords—new era; higher vocational teachers; professional quality; cultivate

\section{INTRODUCTION}

In the 19th national congress of the communist party of China (CPC), general secretary Xi Jinping made it clear that "through long-term efforts, socialism with Chinese characteristics has entered a new era". "The new era" is a new and major political statement on the historical orientation of China's development. After more than 30 years of development, China's education has cultivated a large number of high-quality technical talents, and initially established the modern professional education system. However, with the rapid development of technologies such as Internet and artificial intelligence in our country, higher vocational education is also facing many contradictions, such as the contradiction between the expansion of enrollment and limited teaching resources, the inconsistency between the quality of personnel training of vocational education and the needs of the society, the contradiction between professional accomplishment of teachers and their professional role. Higher vocational teacher is a professional who inherits ideas and trains talents. It is a great vocation for human society to advance and develop. The professionalism of professional teachers determines the quality of training talents, so it is the primary task of the development of higher vocational education in the new era to enhance the professional quality and attainment of teachers in higher vocational colleges.

\section{ThE CONNOTATION OF PROFESSIONAL QUALITY OF ACCOUNTING TEACHER IN HighER VOCATIONAL COLLEGE IN THE NEW ERA}

Up to now, few experts and scholars have made a clear definition of the professional quality of teachers in higher vocational colleges. We often confuse professional quality with professional attainment, but can not replace each other for their similarities. The "quality" is the concept of physiology, it is the innate physical characteristic, which is the innate quality, subsequently, and the acquired quality is also included, such as character, ability and so on. The simple explanation of "attainment" is the quality cultivation, the emphasis on training, cultivation, nurturance, and upbringing. From this it can be seen that the quality has the static attribute, and the accomplishment is the dynamic process, emphasizing the ability, quality and accomplishment by the acquired learning and the practice. Impart knowledge and cultivate people is the sacred duty of teachers, and the key to competent teachers lies in whether they have good professional qualities.

With the development of social politics, economy and information technology, the professional quality of higher vocational teachers must be repositioned. This paper argues that the professional quality of higher vocational teachers in the new era should include seven accomplishments: First of all, professional ethics. Teachers' professional ethics is the moral norm that teachers should follow in teaching practice. The teacher's words and deeds affect the students, teachers must be loyal to their occupation, and they should have good working attitude and working enthusiasm. Second, it is knowledge attainment. Higher vocational teachers not only need to have rich theoretical knowledge, but also have practical knowledge, knowledge includes professional knowledge and comprehensive knowledge, such as historical knowledge, legal knowledge, education knowledge and scientific research, the professional knowledge of higher vocational teachers is the foundation, and the development and promotion must have rich comprehensive knowledge. The third is the ability attainment. It is necessary for teachers to impart their knowledge to students, according to the quality of students or in different teaching environments, teachers should use different teaching methods to guide students' interests and develop students' potential. The teacher must have the excellent teaching ability of education to ensure the teaching efficiency and quality. Fourth, it is physical and mental attainment. The body is the capital of revolution, the physical 
and mental health are the basis of teaching, but also the basis of correctly guiding and helping students to establish a correct outlook on life and values. Fifth, it is information attainment. Information literacy refers to the information processing skills and the ability to screen, identify and use information in a society where information technology is highly developed. In the age of the Internet, teachers can't teach by just a piece of chalk, a textbook, a blackboard or a classroom. Teachers should make full use of information technology to serve education and teaching, such as micro-course, MOOC, flipped classroom and so on. Sixth, it is scientific research attainment. Teaching and scientific research are closely related to each other. The summary of teaching rules, the progress of technology and the development of human beings need scientific research. As educators who have the knowledge of the forefront, they should undertake this responsibility. Finally, it is innovation attainment. Innovative literacy refers to the cultivation of innovative spirit and innovative abilities, including daring to be pioneers, daring to doubt and creative thinking and so on. Higher vocational colleges and universities are important bases for training high quality and skilled talents, which is the birthplace of technological innovation and an important link of national innovation system. If the higher vocational teachers have only general research ability, but have not integrated the innovation factor into the scientific research, then it will not be able to meet the needs of education development and social economic development in higher vocational colleges. If the higher vocational teachers have only general research ability, but have not integrated the innovation factor into the scientific research, they will not be able to meet the needs of higher vocational education and social economic development.

\section{The Path of Cultivating Teacher' Professional ACCOMPLISHMENT IN NEW ERA}

The professional quality of teachers refers to the comprehensive ability and quality of teachers in the professional process. Among these seven accomplishments, professional ethics is the prerequisite, knowledge and ability attainment are the basis, physical and mental attainment is the guarantee, information attainment is the support, scientific research attainment is the source, innovation attainment is the impetus. Teachers' professional quality is related to the construction of high-quality teachers, which is related to the cultivation of high-quality talents. The good quality of students depends on the guidance and demonstration of teachers with good professional quality. Only high-quality teachers can cultivate high-quality students. Therefore, it is very important to improve the professional quality of teachers, but it can not be accomplished overnight. Only long-term and persistent cultivation can improve the professional quality of teachers. Based on the analysis of the connotation of teachers' professional quality in the new era, this paper puts forward the basic path of cultivating the professional quality of teachers in higher vocational colleges in the new era:

The cultivation of teachers' professional ethics should be put in the first place. First of all, choose the political integrity and professional competence of teachers in the selection. Teachers are different from other jobs, we cultivate the future successor of the motherland, especially the teachers in higher vocational colleges, and we are the last mentor of students entering the job, which directly affect the spiritual growth and professional development of students. Secondly, to normalize the teacher's morality, the teacher ethos should keep the alarm bells ringing, and the selection of model teachers as demonstration pioneers. Furthermore, the teacher's moral style should be regarded as the primary condition for the selection of excellent teachers, annual assessment and professional title promotion, and the teacher who has the problem of morality can be defeated by one vote. In addition, it is the combination of the school spirit, the teachers' style and the construction of the study style, which forms a good atmosphere. The external environment is a part of the influence, and the teacher selfimprovement and self-internalization are the fundamental factors.

The key is the cultivation of knowledge attainment and capability attainment. Teachers of higher vocational colleges are different from ordinary universities and secondary vocational school. Teachers in higher vocational colleges have the dual characteristics of "higher" and "occupational". "Higher" refers to a higher level of knowledge; "occupation" refers to strong practical knowledge, which requires higher vocational teachers' long-term learning and practice. At present, teachers in higher vocational colleges generally come from graduate students, including postgraduates and doctoral students, with rich theoretical knowledge, but the problem is that profound theoretical knowledge, narrow knowledge system and zero practical knowledge are not suitable for higher vocational education. In addition, the teaching effect is seriously influenced by outdated teaching concept, single teaching method and lack of expression. Therefore, strengthening teacher cultivation is the key to improve the teaching quality of education. Before becoming an official teacher, a new teacher must go to practice the enterprise, understand the enterprise demand for talent, working process of the enterprise and professional skill, only in this way to combine the theory with practice, perfect the new and old teachers' guidance system, and to promote the rapid growth of new teachers. Second, it is the cultivation of teachers' professional development. The new teachers may have an occupational fatigue stage after the period of vocational adjustment, so it is important to arouse the enthusiasm of teachers. Through professional title promotion, cultivating backbone teachers, excellent teachers and professional leaders, let them become the backbone of education teaching. Third, provide more opportunities for training and learning. Teaching cannot be a frog in the well. Teachers should learn advanced education teaching ideas, methods and latest research results, and learn from the excellent experience, improve their accomplishment through long-term accumulation and precipitation.

The cultivation of physical and mental health attainment is guaranteed. In 1989 the world health organization put forward the new concept of health in the 21st century: "health is not only the body without disease, but also includes mental health, social adaptation and good morality, and with the above four aspects, we will be completely healthy people." [1] Of teachers in higher vocational colleges at present, the physical and 
mental health is not optimistic, the body sub-health, there are more and more psychological problems such as selfish, no progress, irresponsible, lack of cooperation spirit and ability to bear setbacks, and even more anti-social and anti human psychology. Therefore, the higher vocational colleges should pay close attention to teachers' physical and mental health, regular physical examination, and concern about the growth of teachers, discover teachers' difficulties in time and help teachers to solve problems so that each teacher can feel the warmth of the socialist family. Teachers also should master some techniques to relieve stress and resist setbacks, improve the methods for correctly resolving conflicts and handling problems, adjust the mentality, cultivate their strong, optimistic, open-minded and confident personality. Therefore, young teachers must be psychologically healthy, only mental health teachers can train students with mental health.

The cultivation of information attainment is a new requirement of teachers in the new era. First of all, we must realize that the information age has come and the informatization has a great impact on education teaching. Secondly, make full use of network information resources and technical means to serve educational teaching and scientific research. In addition, information screening, information processing, information evaluation, information tracking and other abilities must be available in rapidly changing information. Traditional cramming teaching cannot meet the demands of the new age, the mixed teaching mode of online and offline is the inevitable result of "Internet + education". We have to master the information technology software, flexible use the information technology teaching methods to provide technical support for education and teaching.

The cultivation of scientific research literacy is the source of teachers' development in the new era. Teaching and research are two basic tasks of teachers, some teachers in higher vocational colleges disagree with this statement, and they believe that the task of higher vocational teachers is teaching. Just think, if the teacher only completes the teaching work, but does not reflect the teaching and summarize the teaching, how can the teaching and the education progress? The five thousand years of civilization in China is based on the experience of the ancients. Only constant research, exploration and improvement will continue to progress and development. Therefore, it is necessary to correct "the only teaching theory", to put teaching and scientific research in the same important position, actively participate in investigation and research, declare the subject actively and form a scientific research team, so as to continuously develop.

The cultivation of innovation attainment is the impetus for the development of teachers in the new era. During the "two sessions" in March 2015, general secretary Xi Jinping put forward that "innovation is the first power to lead development", and in October of the same year, he put forward innovation drive as one of the core strategies for China's development. To make innovation the first impetus of China's development, talent must be the first resource to support development. Higher education is the territory of cultivating high-caliber talents. In order to make the trained people have the innovation attainment, the teachers must have the innovative quality first. Both the development of China and
China's higher education are inseparable from the innovative talents. Where does innovation come from? Innovation comes from practice, research and thinking.

\section{CONCLUSION}

The new era puts forward new requirements for the professional attainment of teachers in higher vocational colleges, and also gives teachers a new responsibility in the new era. Teachers in higher vocational colleges should constantly keep up with the demands of the times, adapt to the changes of professional roles, and actively promote their professional accomplishment on the basis of fully recognizing the professional attainment. At the same time of the higher vocational colleges to strengthen the connotation construction and promote the school characteristics, pay attention to cultivation of teacher professional attainment, and strive to build a teacher team that can adapt to the new needs of the times and have good occupation accomplishment and be able to assume the important task of cultivating high-quality skilled talents.

\section{REFERENCES}

[1] Han Bin. A Study on the Construction of Professional Ethics of Collage Teacher [J]. Journal of Tianzhong University, 2011(10): 61-61

[2] Zhang Xinwen, Zhang Xinyue. In the New Era of Young College Teachers' Occupation Accomplishment [J]. Journal of Hebei North University, 2012 (4): 86-88

[3] Wang Yuling. Professional Accomplishment and Promotion of Teachers in Higher Vocational Colleges [J]. Journal of Wuhu Institute of Technology, 2012 (1): 66-68

[4] Wang Xin. Research on the Development of Core Attainment of Young Teachers in Higher Vocational and Technical Colleges [J]. Vocational Technology, 2017 (9): 1-6

[5] Wang Xianghong, Ding Jinchang. The Role Orientation and Professional Accomplishment of Higher Vocational College Teachers [J].Nigher Engineering Education Research, 2014 (4): 168-173

[6] Qin Fen, the Cross-boundary Coordination and Path Selection of Teacher Construction System in Higher Vocational Education [J]. Vocational Education Forum, 2017 (23): 9-12 